\title{
Problemy funkcjonowania Funduszu Rezerwy Demograficznej w Polsce
}

\author{
KAMILA SCHNEIDER \\ mgr, Centrum Rachunkowo-Skarbowe w Szczecinie \\ e-mail: kkschneider@interia.pl
}

SŁoWA KLUCzOWE zmiany demograficzne, rezerwy emerytalne, system emerytalny

Fundusz Rezerwy Demograficznej wszedł w życie w 2002 roku jako państwowy, rezerwowy fundusz emerytalny, mający zabezpieczać stabilność systemu emerytalnego i łagodzić problemy związane ze starzeniem się społeczeństwa.

$\mathrm{Cel}$ - charakterystyka funkcjonowania Funduszu Rezerwy Demograficznej w latach 2002-2017 oraz plany jego wzrostu do 2025 roku. Fundusz ten utworzono w celu gromadzenia i pomnażania środków przeznaczonych w przyszłości na uzupełnienie niedoborów funduszu emerytalnego.

Metodyka badania - w artykule wykorzystano metody analizy jakościowej ujmującej badane związki i zależności w formie opisowej, werbalnej, nie próbując nadać im ilościowego, mierzalnego wyrazu. Opracowanie powstało na podstawie analizy literatury oraz danych statystycznych dotyczących Funduszu Rezerwy Demograficznej i Funduszu Ubezpieczeń Społecznych w Polsce.

Wynik - stwierdzono, że wraz z wprowadzeniem reformy emerytalnej w 1999 roku istotnie zmieniły się zasady przyznawania i obliczania świadczeń emerytalnych. Reforma podyktowana była niekorzystnymi prognozami demograficznymi, które wskazywały na groźbę niewypłacalności dotychczasowego systemu emerytalnego.

Wartość - w artykule przedstawiono problemy prognozowanych zmian w funkcjonowaniu Funduszu Rezerwy Demograficznej, które powinny być w najbliższym czasie dokonane w Polsce.

Artykuł ma charakter przyczynkowski.

\section{Problems functioning of the demographic reserve fund in Poland}

KEYWORDS Demographic changes, pension provisions, pension system

The Demographic Reserve Fund entered into force in 2002 as a state pension reserve fund intended to safeguard the stability of the pension system and alleviate the problems of aging.

Purpose - to characterize the functioning of the Demographic Reserve Fund in the years 2002 2017 and its growth plans until 2025. This fund was created to accumulate and multiply the funds earmarked for the future to supplement the pension fund deficits.

Methodology - the paper uses methods of qualitative analysis of the studied relationships and relationships in descriptive and verbal form without attempting to give them quantitative, measurable word. The study was based on an analysis of literature and statistical data on the Demographic Reserve Fund and the Social Insurance Fund in Poland.

Findings - as a result of the study it was stated that with the introduction of the pension reform in 1999 the rules of granting and calculating pension benefits changed considerably. The reform 
was dictated by unfavorable demographic projections that pointed to the threat of insolvency of the current pension system.

Value - the article presents the problems of forecast changes in the functioning of the Demographic Reserve Fund, which should be made in Poland in the nearest future.

This article is of a contributing character.

\section{Wprowadzenie}

Funkcjonujący w Polsce od 1999 roku powszechny system emerytalny oparty jest na dwóch obowiązkowych filarach - repartycyjnym (ZUS), czyli systemie, w którym zbierane składki społeczne, płacone przez obecnie pracujących są wypłacane aktualnym emerytom, oraz na filarze kapitałowym (OFE) zasilanym częścią składki ubezpieczenia społecznego płaconej przez obecnie pracujących i przekazywanej na ich indywidualne konta w funduszu emerytalnym, który będzie w przyszłości wypłacał im emeryturę.

Formułę obliczania świadczenia bazującą na zasadzie zdefiniowanego świadczenia, zastąpiono formułą zdefiniowanej składki, a w miejsce jednoelementowego systemu repartycyjnego powołano wielofilarowy system o finansowaniu mieszanym, repartycyjno-kapitałowym. Powodem tego był przewidywany szybszy wzrost liczby osób w wieku emerytalnym w stosunku do liczby osób czynnych zawodowo, zwany procesem starzenia się społeczeństw (ageing populations). Jest to obecnie jeden z głównych problemów polityki społecznej i finansowej na świecie, a w szczególności w państwach Unii Europejskiej oraz w Polsce.

Ze względu na pogarszającą się sytuację demograficzną, czyli spadek liczby osób w wieku produkcyjnym w stosunku do liczby osób uprawnionych do świadczeń emerytalnych i jej wpływ na finansowaną repartycyjnie część systemu emerytalnego, utworzono Fundusz Rezerwy Demograficznej. Fundusz ten miał zapewnić funkcjonowanie systemu w warunkach sprawiedliwości międzypokoleniowej, rozumianej jako równe traktowanie poszczególnych pokoleń i uwzględnienie interesów pokoleń przyszłych. Zgodnie z przyjętymi założeniami środki zgromadzone w Funduszu Rezerw Demograficznych miały być wykorzystane wyłącznie w razie niekorzystnej sytuacji demograficznej, przede wszystkim w latach 2020-2050. Według prognoz, Fundusze te będą niezbędne do uzupełniania braków na kontach funduszu emerytalnego. Wskazano też na zależności pomiędzy procesem starzenia się społeczeństwa a stabilnością budżetu państwa.

\section{Fundusz Rezerwy Demograficznej w Polsce}

W świetle regulacji zawartych w Ustawie z 13 października 1998 roku o systemie ubezpieczeń społecznych (Dz.U. nr 137, poz. 887 ze zm.) Fundusz Rezerwy Demograficznej jest tworzony z środków pozostających w funduszu emerytalnym na koniec każdego roku kalendarzowego, pomniejszonych o kwotę niezbędną na wypłaty świadczeń w pierwszym miesiącu kolejnego roku kalendarzowego (art. 58 ust. 1 ustawy). Zgodnie z ustawą Fundusz jest także zasilany ze:

- środków pochodzących z prywatyzacji mienia Skarbu Państwa, przekazanych do funduszu, 
- środków z kolejnych wpłat pochodzących z części składki na ubezpieczenie emerytalne, odprowadzane przez Zakład Ubezpieczeń Społecznych (ZUS) do funduszu,

- środków stanowiących przychody z lokowania środków Funduszu.

Reforma wprowadzająca trzy filary emerytalne finansowania świadczeń miała na celu stopniowe uzupełnianie systemu repartycyjnego o rozwiązania kapitałowe, podczas gdy Fundusz Rezerwy Demograficznej miał zapewnić bezpieczeństwo wypłat z Funduszu Ubezpieczeń Społecznych z zastrzeżeniem, że jego aktywa mogą być wykorzystane od 2009 roku.

Wprowadzono jednocześnie ograniczenia inwestycyjne polegające na tym, że środki Funduszu mogą być lokowane tylko w krajowe papiery wartościowe (skarbowe papiery wartościowe, komunalne papiery wartościowe, akcje dopuszczone do publicznego obrotu, zabezpieczone obligacje komercyjne). Szczegółowe zasady lokowania środków funduszu reguluje rozporządzenie Ministra Pracy i Polityki Społecznej z 29 maja 2009 roku (Dz.U. nr 92, poz. 757). Zgodnie z obowiązującym stanem prawnym udział poszczególnych papierów wartościowych nie może przekraczać:

- 100\% - w odniesieniu do bonów, obligacji skarbowych i innych papierów wartościowych Skarbu Państwa,

- 20\% - w odniesieniu do papierów wartościowych emitowanych przez gminy, związki gmin i miasto stołeczne Warszawa,

- $80 \%$ - dla dłużnych papierów wartościowych gwarantowanych przez Skarb Państwa,

- 30\% - dla akcji zdematerializowanych,

- 20\% - dla obligacji zdematerializowanych,

- 5\% - w przypadku inwestycji dokonywanych w obligacje emitowane przez spółki publiczne,

- 40\% - dla depozytów bankowych i bankowych papierów wartościowych.

W portalu inwestycyjnym Funduszu znajdowały się wyłącznie obligacje skarbowe $(85,5 \%)$ oraz akcje (14,5\%). Łącznie suma lokat niewyemitowanych przez Skarb Państwa i jednostki samorządowe nie może przekroczyć 40\% wartości Funduszu.

Zmniejszono także istotnie wielkość odpisu składki na ubezpieczenia emerytalne odprowadzane do Funduszu z zakładanego poziomu 1\% do 0,1\% w latach 2002-2003. Przyjęto też zasadę corocznego, począwszy od roku 2004 roku podwyższenia odpisu o $0,05 \%$.

Poziom aktywów Funduszu Rezerwy Demograficznej jest niewspółmiernie niski w stosunku do potrzeb. Stan Funduszu na koniec 2016 roku wynosił 21,8 mld zł, a ZUS wypłaca miesięcznie ok. 12 mld zł - czyli środków z Funduszu wystarcza na dwa miesiące świadczeń emerytalnych. Planowany stan funduszu na rok 2017 wynosi 23,7 mld zł (Fundusz...).

\section{Zagrożenia i szanse dla funkcjonowania Funduszu Rezerwy Demograficznej}

Wydatki na świadczenia emerytalno-rentowe stanowią jedną z najważniejszych pozycji w systemie polskich finansów publicznych, zarówno ze względu na ich wielkość, jak i znaczenie społeczne. Odprowadzane przez osoby aktywne zawodowo składki nie są w stanie pokryć bieżących wypłat. Powstały w ten sposób deficyt pokrywany jest z budżetu państwa i stanowi obecnie poważne obciążenie dla finansów publicznych, ponieważ udzielane przez budżet dotacje i pożyczki powiększają dług publiczny. 
Wzrost deficytu sektora finansów publicznych był główną przesłanką do wprowadzenia z początkiem lutego 2014 roku zmian w przekazywaniu składek do OFE i dokonania ponownej reformy systemu emerytalnego. W rezultacie tych zmian nastąpiło przejęcie przez ZUS aktywów od OFE o wartości 153,2 mld zł, które następnie zostały przekazane na rzecz Skarbu Państwa, reprezentowanego przez Ministra Finansów, w celu ich umorzenia (obligacje skarbowe) oraz do Funduszu Rezerwy Demograficznej i emerytalnego Funduszu Ubezpieczeń Społecznych.

Realizacja przyjętych rozwiązań ustawowych nie rozwiąże jednak w dłuższej perspektywie problemu deficytu Funduszu Ubezpieczeń Społecznych. Mimo przewidywanego zwiększenia wpływów z tytułu składek, a także przenoszenia środków w ramach tzw. suwaka (mechanizm, dzięki któremu 10 lat przed osiągnięciem wieku emerytalnego środki z OFE będą stopniowo przenoszone na fundusz emerytalny FUS i ewidencjonowane na prowadzonym przez ZUS indywidualnym subkoncie przyszłego emeryta), ZUS przewiduje dalszy wzrost deficytu FUS.

Pogłębiający się deficyt Funduszu Ubezpieczeń Społecznych wskazuje, że w dłuższej perspektywie, bez wsparcia z budżetu państwa, może nie wystarczyć środków na wypłatę świadczeń emerytalnych. Głównymi przyczynami są z jednej strony niski wskaźnik urodzeń i emigracja, a z drugiej wchodzenie w wiek emerytalny roczników z wyżu demograficznego po 1945 roku oraz wydłużanie się długości życia.

Do Funduszu Rezerwy Demograficznej 3 lutego 2014 roku trafiło 19 mld zł. Była to część aktywów zabranych w Otwartym Funduszom Emerytalnym Proces upłynniania papierów wartościowych, które Fundusz dostał z OFE zajmie jednak sporo czasu. Przebieg tej operacji zależy od terminu zapadalności poszczególnych papierów. Zanim jednak upłynnienie nastąpi, Fundusz będzie zarządzał pokaźnymi aktywami (Schneider, 2016, s. 666).

Analizując funkcjonowanie Funduszu Rezerwy Demograficznej w Polsce, można wskazać trzy najistotniejsze problemy (Adamska-Mieruszewska, 2015, s. 435):

- źródła finansowania Funduszu,

- możliwości inwestycyjne,

- przedwczesne wypłaty z Funduszu Rezerwy Demograficznej na rzecz Funduszu Ubezpieczeń Społecznych.

Fundusz Rezerwy Demograficznej rozpoczął działalność dopiero w 2002 roku, czyli z ponad trzyletnim opóźnieniem, co spowodowało zmniejszenie zasilania do $0,8 \%$ PKB, a nie planowanego 4\% (Gołębiowska, 2014, s. 49). Poza tym środki były zmniejszane z planowanych 1\% do $0,1 \%$, a od 2009 roku ustabilizowały się na poziomie $0,35 \%$. Do 2009 roku nie były również przekazywane środki z prywatyzacji mienia Skarbu Państwa. Pierwsza ich wpłata nastąpiła w lutym 2009 roku.

Poziom aktywów Funduszu Rezerwy Demograficznej jest niewspółmiernie niski w stosunku do potrzeb. Na przykład, planowana na 2017 roku kwota świadczeń emerytalnych wypłacanych z Funduszu Ubezpieczeń Społecznych wyniesie 211,8 mld zł, a środki zgromadzone w Funduszu Rezerwy Demograficznej wyniosą na koniec 2017 roku około 23,7 mld zł. Środki zgromadzone w Funduszu stanowią więc 11,2\% planowanych różnych wydatków na emerytury. Plany na rok 2017 pokazują, że źródło z przychodów prywatyzacyjnych zaczyna się wyczerpywać, a to oznacza malejącą dynamikę aktywów Funduszu i może w konsekwencji skutkować sięgnięciem po pozostałe rezerwy. Prognoza wpływów w wydatkach FUS na lata 2017-2022 przygotowana przez ZUS zakłada trzy scenariusze: 
1. Mimo nabycia świadczeń emerytalnych od 1 października 2017 roku dodatkowych 350 tys. osób w związku z obniżeniem wieku emerytalnego, rząd zaplanował na 2018 roku dziurę w ZUS na około 53,5 mld zł.

2. W 2018 roku deficyt wyniesie 54,7 mld zł. Wyliczenie to oparte jest jednak na bardzo optymistycznych założeniach Ministerstwa Finansów, że część uprawnionych osób nie przejdzie na emeryturę.

3. Wszyscy uprawnieni zdecydują się przejść na emeryturę i wrośnie bezrobocie, a to oznacza konieczność dofinansowania przez państwo aż 63 mld zł deficytu.

ZUS prognozuje, że dziura w FUS będzie rosła i w 2022 roku może wynosić 85 mld zł rocznie. Mimo prognoz podawanych przez ZUS, rząd nie ma konkretnych pomysłów na powstrzymanie fali przejść na emerytury. Konkretnego projektu zmian przepisów też brakuje. (Rzemek, 2017).

Drugim problemem w funkcjonowaniu Funduszu Rezerw Demograficznych są przedwczesne wypłaty do Funduszu Ubezpieczeń Społecznych. Pieniędzy nie przybywa dlatego, że rząd, tłumacząc się trudną sytuacją finansową, uszczuplał Fundusz: w 2010 roku o 7,5 mld zł, w 2011 roku o 4,0 mld zł, w 2012 roku o 2,8 mld zł i w latach 2013-2014 po 2,5 mld zł. W 2015 i 2016 roku Fundusz nie został uszczuplony, niewykluczone jednak, że w latach następnych środki Funduszu rząd będzie chciał wydać na jakieś inne cele - na przykład na finansowanie wydatków na program 500 plus z Funduszu Rezerwy Demograficznej o czym informowała członkini Rady Polityki Pieniężnej Grażyna Ancyparowicz¹. A finanse państwa na 2017 rok są napięte. Rząd tylko na program 500 plus będzie potrzebował w tym roku 23 mld zł.

\section{Problemy funkcjonowania FRD w latach $2017-2025$ w świetle rosnącego zadłużenia FUS}

Od 1 października 2017 roku Polki znów mają pracować do 60 a mężczyźni do 65 roku życia (zamiast do 67). Ustawę o obniżeniu wieku emerytalnego podpisał prezydent A. Duda. Według wyliczeń rządu obniżenie wieku emerytalnego będzie kosztować nawet 18 mld zł rocznie.

W 2018 roku wpływy do Funduszu Ubezpieczeń Społecznych zmaleją wskutek obniżenia wieku emerytalnego o 3 mld zł, a wydatki wzrosną o 14,4 mld zł. Łącznie niedobór w FUS wyniesie 17,4 mld zł. Jeszcze gorzej będzie w latach 2020-2025, kiedy obniżenie wieku będzie kosztować rocznie do 18 mld zł. Łącznie więc do 2025 roku budżet będzie musiał mieć dodatkowo 88,7 mld zł. Rząd powinien zmniejszyć wydatki, ograniczając przywileje emerytalne wybranych grup zawodowych, np. służb mundurowych, górników, ale tego nie zrobi. Do końca kadencji pieniądze można wziąć z OFE (153 mld zł ulokowanych m.in. w akcjach spółek) lub wybrać całkowicie kwoty z Funduszu Rezerwy Demograficznej (21 mld zł). Ale co później? Koszty obniżenia wieku emerytalnego w 2018 roku zostaną prawdopodobnie sfinansowane ze środków pochodzących z likwidacji OFE i to z niego będą finansowane niedobory w ZUS.

Prognoza przygotowana przez ZUS wskazuje, że największe koszty związane z obniżką wieku emerytalnego budżet odczuje dopiero w latach 2020-2022. Wyjściem z sytuacji jest

\footnotetext{
${ }^{1}$ http://wyborcza.pl/7,155287,21286342,pieniadze-przyszlych-emerytow-pojda-na-500-tak-chce-czlonkini.html? disableRedirects $=$ true.
} 
wyrównanie wieku emerytalnego kobiet i mężczyzn na poziomie 66 lat - twierdzi Jeremi Mordasewicz - członek rady nadzorczej ZUS, który krytykuje pomysł rządu, aby dawać premię w wysokości 5 tys. zł rocznie za dłuższą pracę, co proponuje wicepremier Morawiecki. J. Mordasewicz nie zgadza się na ograniczenie możliwości zarabiania na emeryturze, bowiem świadczenia będą tak niskie, że emeryci będą musieli dorabiać, aby utrzymać swoją egzystencję.

Środki na emerytury można uzyskać też z kont Funduszu Rezerwy Demograficznej, jednak teoretycznie pieniądze te powinny być wykorzystywane tylko na wypłaty emerytur. Ale rząd może wydać je na dowolny cel, wystarczy, że w danym roku przekaże całość pieniędzy z Funduszu na zmniejszenie dotacji z budżetu państwa. „Oszczędności” będzie mógł więc wydać na dowolne cele, które uzna za niezbędne.

Znikną też wpływy do Funduszu z prywatyzacji. Obecny rząd nie zamierza tego robić. Zamiast sprzedawać zakłady, rząd będzie odbudowywać majątek - powiedział minister Henryk Kowalczyk na konferencji „Odpowiedzialność przedsiębiorców za Polskę” w Toruniu (4.02.2017 r.).

Pozostają jeszcze środki w Otwartych Funduszach Emerytalnych - ale niedługo. Obecnie 16,4 mln przyszłych emerytów ma w OFE składki w kwocie 153 mld zł. Rząd planuje dokonać zmian w funkcjonowaniu i przekształcić je w fundusze inwestycyjne.

Jedna czwarta oszczędności (ok. 40 mld zł) przejdzie do Funduszu Rezerwy Demograficznej, a równowartość tej kwoty zostanie zapisana na naszych wirtualnych kontach w ZUS. Pozostałe 75\% pieniędzy (czyli 113 mld zł), które są w OFE staną się naszymi prywatnymi oszczędnościami w trzecim filarze emerytalnym. Środki te nie będą mogły być wykorzystane aż do momentu przejścia na emeryturę.

Analizując dotychczasowe działanie Funduszu Rezerwy Demograficznej, należy stwierdzić, że Fundusz nie będzie w stanie sprostać celom, dla których go powołano. W wyniku wydłużenia się trwania życia ludności coraz więcej osób dożywa wieku emerytalnego i wzrasta długość okresu przebywania na emeryturze. Jednocześnie nastąpił spadek urodzeń dzieci. Przybywa też emerytów w stosunku do osób pracujących. Obecnie na jednego pracującego przypadają trzy osoby pobierające świadczenia emerytalne. Ponad 2 mln osób wyjechało za pracą do Europy Zachodniej, co także wpływa na braki środków w Funduszu.

Biorąc pod uwagę zmiany demograficzne, można przyjąć, że po 2020 roku na wypłatę emerytur dla obecnych pięćdziesięciokilkulatków może zabraknąć ok. 46 mld zł rocznie, a w 2025 roku - nawet 63 mld zł. Może dojść do sytuacji, że w momencie kryzysowym dla systemu może zabraknąć środków na pełną obsługę świadczeń emerytalnych. Określone w ustawie zasady funkcjonowania Funduszu nie pozwalają uzupełnić braków powstających na koncie, gdyż nie może on zaciągać pożyczek i kredytów. Wypłatę świadczeń emerytalnych z Funduszu Ubezpieczeń Społecznych gwarantuje budżet państwa.

Dopłaty państwa do emerytur w sumie będą większe, gdyż prognozy ZUS nie uwzględniają deficytu pozostałych systemów emerytalnych. Państwo dopłaca jeszcze (Schneider, 2016, s. 652-653):

- do emerytur rolniczego KRUS - 16 mld zł rocznie dla 1,3 mln osób,

- do emerytur służb mundurowych - ponad 13 mld zł rocznie dla 308 tys. osób,

- do tego trzeba doliczyć miliardowe wydatki na renty, zwolnienia chorobowe i inne świadczenia dla sędziów, prokuratorów przechodzących w stan spoczynku. 
W celu naprawy systemu Funduszu Ubezpieczeń Społecznych należy:

- włączyć KRUS do ZUS, ujednolicając zasady przyznawania emerytur dla wszystkich obywateli, w tym rolników,

- oskładkować wszystkie służby mundurowe,

- oskładkować służby sądownicze i prokuratorskie,

- zlikwidować przywileje emerytalne (np. dotyczące emerytur górniczych służb mundurowych).

\section{Podsumowanie}

Utworzenie Funduszu Rezerwy Demograficznej należy ocenić pozytywnie, ponieważ miał wpłynąć na zwiększenie bezpieczeństwa wypłacalności świadczeń z ubezpieczenia emerytalnego, czyli na bezpieczeństwo przyszłych emerytur. W praktyce okazało się jednak, że został on instytucją niezdolną do realizacji swoich celów. Niepokój budzi realna sytuacja finansowa Funduszu związana z jego niedofinansowaniem, a także zbyt wczesnym wykorzystaniem zgromadzonych środków, z transferów z Funduszu, które rozpoczęto w latach 2010-2014.

Podsumowując dyskusję o zasadności przedterminowego wykorzystania środków zgromadzonych w Funduszu Rezerwy Demograficznej, należy stwierdzić, że działania te podyktowane były chęcią ograniczenia długu jawnego przez Ministra Finansów. Wpływają jednak na poprawę oficjalnych statystyk, ograniczając bieżący deficyt budżetowy (Rutecka, 2013, s. 119). Taka kreatywna ewidencja budżetu państwa spowoduje pogorszenie sytuacji finansowej systemu emerytalnego w przyszłości. Fundusz nie sfinansuje jednak zwiększonych wydatków emerytalnych i należy oczekiwać zwiększenia składek lub podatków albo obniżenia poziomu świadczeń emerytalnych. Pytanie, jaki model wybiorą politycy? Jeżeli zmiany pójdą w kierunku ściągnięcia składek od każdego przychodu z każdej umowy, to koszty reformy zostaną przerzucone na przyszłe pokolenie. Można też koszty obniżenia wieku emerytalnego pokrywać z nowego podatku. Rząd powinien wskazać źródło finansowania reformy.

Teraz największym problemem jest kwestia finansowania rosnącego niedoboru w FUS, ale za kilkanaście lat najbardziej pilnym problemem będzie to, że około 70\% kobiet nie dostanie nawet minimalnej emerytury. Kto będzie w stanie zmierzyć się z tym wyzwaniem?

\section{Literatura}

Adamska-Mieruszewska, J. (2015). Funkcjonowanie Funduszu Rezerwy Demograficznej w Polsce na tle rozwiązań światowych. Zeszyty Naukowe Uniwersytetu Szczecińskiego, 855 (74).

Fundusz Rezerwy Demograficznej na rok 2016. Pobrano z: http: //www.bip.zus.pl-finanse-zus i fus/.

Gołębiowska, A. (2014). Funkcjonowanie Funduszu Rezerwy Demograficznej w Polsce - Zasady i zagrożenia. Optimum Studia Ekonomiczne nr 2(68).

Plan finansowy Funduszu Ubezpieczeń Społecznych na rok 2017. Pobrano z: http: //www.zus.pl/bip.

Rzemek, M. (a) (2017). ZUS ostrzega rząd. Rzeczpolspolita, 72 (z 27.03.2017).

Rozporządzenie Ministra Pracy i Polityki Społecznej z 15.02.2002 r. w sprawie nadania statutu Funduszowi Rezerwy Demograficznej (Dz.U. nr 18, poz. 178).

Rozporządzenie Ministra Pracy i Polityki Społecznej z 29.01.2014 r. w sprawie lokowania środków Funduszu Rezerwy Demograficznej (Dz.U. 2014, poz. 152). 
Rozporządzenie Ministra Pracy i Polityki Społecznej z 29.05.2009 r. w sprawie lokowania środków Funduszu Rezerwy Demograficznej. (Dz.U. nr 92, poz. 757).

Rutecka, J. (2013). Fundusz Rezerwy Demograficznej - analiza działalności oraz konsekwencje przedterminowego wykorzystania aktywów. Studia i Prace Kolegium Ekonomiczno-Społecznego SGH, 3.

Schneider, K. (2016). Patologie i oszustwa w finansach publicznych. Szczecin: PTE.

Ustawa z 13.10.1998 r. o systemie ubezpieczeń społecznych (Dz.U. nr 137, poz. 887).

\section{Cytowanie}

Schneider, K. (2016). Problemy funkcjonowania Funduszu Rezerwy Demograficznej w Polsce. Współczesne Finanse. Teoria i Praktyka, 1 (1), 83-90. DOI: 10.18276/wf.2016.1-08. 